bours from damage. There are, however, areas where much more could be done to protect those who suffer. In general, where the laird or factor is permanently resident, satisfactory co-operation and understanding are most easily achieved. Where there is no one of sufficient authority to deal with it on the spot, and the estate concerned is factored from an office outside the Highlands, it is inevitably more difficult.

In some areas where marauding is prevalent there are not enough stalkers and gamekeepers available to deal with the situation. The Commission believes that the widespread marauding taking place throughout the year is probably a symptom of overstocking on recognized deer land in the vicinity, and that the root of all deer 'trouble' is lack of adequate management. The annual kill of hinds, for example, is generally too low; the only way to reduce overlarge stocks is in the culling of hinds. When it is left to an inadequate staff of stalkers or gamekeepers this most important aspect of management is apt to go by default. Sometimes, excessive stocks of deer have been maintained to make allowance for the slaughter done by gangs of poachers. Whatever justification there may have been for this practice in the past, it no longer exists.

Estates in some areas are seriously handicapped in stag shooting by the incursion of the public in the later summer and autumn. If such estates are to be enabled to carry out their obligations during the open (stalking) season, means will have to be found to dissuade the public from disturbing the ground and possibly courting danger to themselves.

\title{
WOMEN ENGINEERS IN THE U.S.S.R.
}

$\mathrm{W}$ OMEN form a much higher proportion of engineers and technologists in the U.S.S.R. than in Western Europe or the United States. A study arranged by the Caroline Haslett Memorial Trust was designed to throw light on the factors giving rise to this high proportion, on the capability of women to benefit from a technical education, and on the employment prospects of women so trained. The study included an investigation in the U.S.S.R. itself, and this was undertaken by Miss L. S. Souter, head of the Mrgnetic Materials Section of the Associated Electrical Industries Research Laboratory, Harlow, and Miss R. Winslade, assistant instruments group manager, Research and Control Instruments, Ltd.

In their report* the authors show that, under the national educational system of the U.S.S.R., coeducation of boys and girls is the general practice. In 1943 the sexes were separated into different schools, but, after a ten-year trial, the experiment was abandoned under pressure of public opinion. Only one trace of the separation remains; while boys of 11-14 are having carpentry lessons, girls are being taught domestic science. For all other subjects boys and girls attend the same classes, and, with few exceptions, girls have the same choice of specialities as boys. Comparicons of the performance of men and women as engineers have been made easier by this common educational background. Although the right of entry into university was not fully extended to women until after the 1917 revolution, the limited right of attendance at higher educational courses (some specially cet up for women) was gxanted in 1905 as a result of revolutionary developments at that time and, by 1907, a number of technical institutions were open. There are records of women attending engineering classes at polytechnics during 1907-9, but the numbers were comparatively small.

Equality of opportunity brought the proportion of women in some of the universities up to 50 per cent in 1920. While at the higher medical schools 80-85 per cent of the students were women, the entry into the engineering schools appears to have been much slower. Even as late as 1928, only 1 per

* Caroline Haslett Memorial Trust. Women Engineers in the U.S.S.R.: a Study of the Education, Employment and Prospects of Women Engineers in the U.S.S.R., carried out under the auspices of Pp. 28. (London: The Caroline Haslett Memorial Trust, 25 Foubert's Place, W.1, 1960). cent of the students of thermal power were women; the proportions of women students taking chemistry, physics and mathematics courses was much higher.

The rate of entry of girls into engineering at a lower level appears to have been somewhat faster, and was encouraged by the all-out drive to make good the technical backwardness of the country as a whole. By 1929, 37.1 per cent of pupils at the technicums or trade schools were girls.

In the middle 1930's the entry of girls into engineering institutes increased gradually and then rapidly, partly as a result of the drive to develop industry throughout the country. By 1938 about 28 per cent of the engineoring students were women, and by the end of the decade the 30 per cent mark appears to have been passed. Young men were sharing engineering classes with a high proportion of girls and were taught by staffs which in 1939 included 23 per cent women. They came to take it for granted that engineering was not only a possible but also a suitable profession for women.

The increasing proportion of women students in engineering institutes continued after the Second World. War, but the rate of increase was falling; the numbers are now increasing slowly, and there has been negligible change in the 33-35 per cent level reached in the late 1940's. There has, however, been a considerable increase in the number of women holding higher engineering qualifications. The industries which attract women engineers show marked differences from Great Britain. Here, industries with a long tradition of women operatives are slow to attract (or accept) women engineers; in the U.S.S.R. it is the textile and food industries which have the highest proportion of women engineers. The high proportion of women engineers in the U.S.S.R. was so much taken for granted that the reasons for the Souter-Winslade study were frequently called into question and led to no little amusement.

Throughout the U.S.S.R. women are forbidden to take up any branch of engineering which is considered to be prejudicial to health. Some examples are: (1) at trade-level-girls are not permitted to service television sets because of the danger of radia. tion and because of the heavy weights of the sets themselves; they are permitted to train as telephone service engineers, but not allowed to carry out work involving the climbing of roofs or poles, or to work 
on underground cables; (2) at professional levelgirls are permitted to study as mining engineers and may exercise their profession in surface jobs, but they are forbidden to work underground.

Strong attempts are made to discourage girls from some types of work which are regarded as unsuitablo although not forbidden by law. These posts fall into the categories of physically dangerous or arduous, such as forging or rolling processes, or unpleasant, such as some of the processes of chemical engineering. As a general rule, there are fewer women in heavy industry than in the textiles, food, watch and clock industries.

The Krasny Oktyabr sweet factory appears to be typical of the food industry, and here a women occupies the post of director, and women are in eharge of the departments concerned with planning (engineering economist), costing (economist), analytical planning, technical control of output, mechanical engineering and design. The women acting in a supervisory capacity are: the deputy chief mechanical engineer, 15-20 design engineers and 2-4 production shop supervisors. Women head most of the ancillary departments, including book-keeping, library, polyclinic and canteen. Men occupy the posts of commercial director (combined with the post of vice-director), chief engineer, chief mechanical engineer, head of wages department and 2-4 of the production shop supervisors. There was general agreement that girls and women show a particular preference for engineering economies, engineering design, laboratory work and teaching. Engineering economics, in particular, is popular with girls, and, until the eurrent year, made up 95 per cent of the students of faculty in the Leningrad Polytechnic. Engineering economics includes the economy of distribution and supply of energy, metallurgical production and processing, mechanical engineering, machine construction and mechanization of working processes by automation.

Preference for engineering design work was illustrated in the teaching institutes by the number of women students in courses on airfield construction, road, bridge and tunnel design at the Institute of Ways of Communication; the figure of 35 per cent compared with 10 per cent in the mechanical faculties.

The attraction of research work was evident, and the proportion of women in all types of laboratories, such as those concerned with fundamental research, development, works-aid, and material or process control, was much higher than the 28 per cent average. Almost all the research laboratories of the Likhachiov Motor Works are headed by women and some completely staffed by women. 50 per cent of the staff of the Research Institute of Common Technologies are women, and here women head a fair proportion of the sections. 60 per cent of the staff of the Research Institute for Communications (covering telecommunications) are women.

There is a general shortage of teachers, and there is a drive to make more junior teaching posts more attractive. Engineers are released from industry to the teaching institutions on a part-time basis; no extra hours per week are worked and extra pay is given. Nevertheless, it is difficult to attract people to teaching. In spite of the fact that teaching is said to be fairly high in order of popularity with women, and most teachers of mathematics and physics are women, they comprise only about 20 per cent of the teaching staffs of these institutions, that is, less than the national average among engineers.

Men and women receive equal pay, and there is no reason why women employees should be preferred on this score. The minimum age for retirement for women is 55 compared with 60 for men, but both men and women often continue working for up to ton years after the minimum age.

It was not possible to make a comparable study of the distribution of girls between various trades which are taught in the technicums or of the girls obtaining technical qualifications at junior technical colleges. The authors considered the question of whether or not women in the U.S.S.R. are allowed and encours,ged to enter the engineering professions and also whether they achieve promotion to top positions.

In 1957 women formed 10 per cent of the directors, chief engineers and other leading specialists in the national economy, as opposed to 38 per cent employed as engineers. The total figures for all ranks of engineers show that 28 per cent of the positions are occupied by women.

In the U.S.S.R. Miss Souter and Miss Winslade also examined the objections put up to exclude women from senior positions in engineering in Great Britain. They found that girls were putting up performances in mathematics and physics comparable with boys; although the proportion of prizes going to girls varied from year to year; over a ten-year period they averaged a share of the prizes in relation to the total numbers. There is a slight departure from the general trend in Kharkov where, in the Institute's entrance examination, girls put up a slightly better performance than boys in physics, chemistry and foreign languages, while boys do better in mathematics and Russian. At all stages the adequacy of the mental capacity of women was so taken for granted that some difficulty was experienced in bringing discussion with scientists in the U.S.S.R. to a factual level. Schoolgirls appear to have no inhibitions about tackling technical work, and 40-45 per cent of the technical streams of secondary schools are girls. These girls show much enthusiasm for all types of technical work and, in some schools, bave the reputation of being more accurate with machine tools than boys.

\section{THE DUST CLOUD ABOUT THE EARTH}

$\mathrm{I}^{\mathrm{N}}$ Nature, 189, 127 (1961), Dr. F. L. Whipple discusses four possible explanations for the concentration of dust near the Earth. Of these the most favourable consideration is given to the hypothesis that it originates in collisions between meteorites and the Moon.
I would like to propose as at least equally tenable a fifth hypothesis: that the dust originates from meteorites that graze the Earth's atmosphere. Clearly meteorites that strike the Earth's atmosphere at too large an angle (or with too small an impact parameter) will be burnt up in the conventional way. Clearly, 